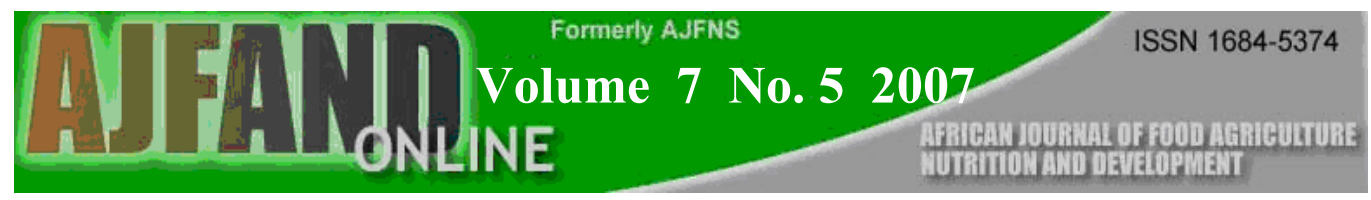

\title{
NUTRITIONAL EVALUATION OF Faidherbia albida SEEDS AND PULP AS SOURCE OF FEEDS FOR LIVESTOCK
}

By

L. G. Hassan ${ }^{1}$, K. J. Umar ${ }^{1}$ and H. Yuguda ${ }^{1}$

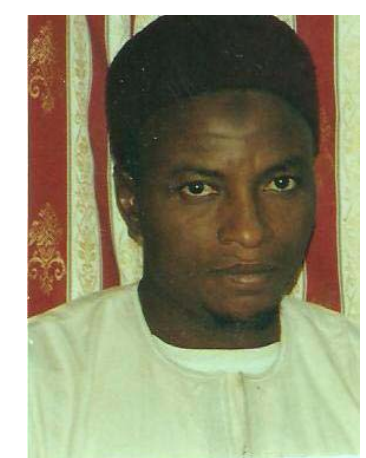

\section{Lawal Gusau Hassan}

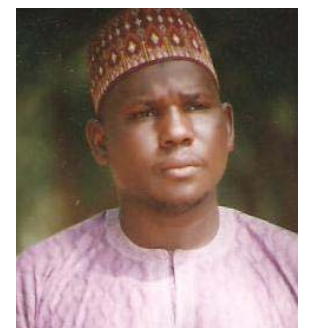

Kabiru Jega Umar

*Corresponding Author: E-mail: 1ghassan2002@yahoo.com

${ }^{1}$ Department of Pure and Applied Chemistry,

Usmanu Danfodiyo University, P.M.B. 2346, Sokoto, Nigeria 


\section{ABSTRACT}

The present study was conducted to find out the nutritional values of Faidherbia albida (Acacia albida) seeds and pulp to be used as components in livestock feeds. The samples were randomly collected from various trees during the period of January to February. The samples were separated, milled and analysed for proximate components and mineral elements using standard methods of the AOAC. Proximate analysis results showed that the concentrations of tested parameters in the seed and the pulp respectively on $\%$ dry matter were: dry matter $(90.0 \pm 0.4 ; 93.3 \pm 0.2)$, ash $(3.3 \pm 0.1 ; 6.7 \pm 0.1)$, crude protein $(20.6 \pm 1.2 ; 19.5 \pm 0.4)$, crude lipid $(13.3 \pm 0.1$; $3.3 \pm 0.1)$, crude fibre $(6.7 \pm 0.1 ; 13.3 \pm 0.2)$, and available carbohydrate $(46.1 \pm 0.1$; $50.53 \pm 0.7)$. The results indicated that the contents of dry matter, ash, crude fibre and available carbohydrate were significantly higher $(\mathrm{p}<0.05)$ in the pulp compared to the seed while the crude lipid values, however, were significantly higher $(p<0.05)$ in seeds compared to pulp. Crude protein values did not differ significantly $(p>0.05)$ between treatment means of seeds and pulp. The estimated energy value was significantly higher $(\mathrm{p}<0.05)$ in the seed $(1,682 \mathrm{~kJ} / 100 \mathrm{~g})$ compared to pulp $(1,363$ $\mathrm{kJ} / 100 \mathrm{~g})$. The results for the mineral analysis indicate that the seeds and pulp contain appreciable concentrations $(\mathrm{mg} / 100 \mathrm{~g})$ of $\mathrm{Ca}(136.6 \pm 5.0 ; 55.0 \pm 5.0) ; \mathrm{Mg}(135.0 \pm$ $2.0 \pm 5.0 ; 84.7 \pm 3.0) ; \mathrm{P}(26.6 \pm 0.9 ; 29.6 \pm 0.7) ; \mathrm{K}(144.5 \pm 0.2 ; 88.8 \pm 0.1) ; \mathrm{Na}(12.5$ $\pm 0.1 ; 6.8 \pm 0.1) ; \mathrm{Fe}(6.2 \pm 0.2 ; 8.8 \pm 0.3) ; \mathrm{Cu}(5.8 \pm 0.1 ; 2.5 \pm 0.1)$ and $\mathrm{Zn}(8.0 \pm 0.1$; $3.0 \pm 0.1)$. Mineral elements in seed are significantly higher $(\mathrm{p}<0.05)$ compared to that of pulp in most cases. From the results it can be inferred that the seed and pulp of $F$. albida could be an important source of feed ingredient for livestock if properly harnessed.

Key words: Feed, Faidherbia albida, Nutrition evaluation 


\section{INTRODUCTION}

Livestock play a vital role in the lives of many people on a global scale, chiefly as a source of income and in the provision of meat and milk, which are considered as first class protein sources. In most developing nations, particularly those within arid and semi-arid regions of sub-Saharan West Africa, livestock production is affected by seasonal variation in the availability and quality of pastures [1]. Even during the period of surplus (rainy season), pastures are low in protein and therefore could not meet nutritional requirements of livestock [2,3]. During the dry season, animals have to be supplemented with high quality rations to avert malnutrition. However, due to economic pressure, many of the small-scale livestock farmers cannot afford to supplement animals with the highly expensive feed ingredients $[2,4]$.

Nigeria is blessed with diverse range of vegetation zones from dense rain forest in the southern part to plain and sandy arid zone in the extreme north. This wide variation gives an enabling environment for different types of flora to grow. Thus, the adverse effects of malnutrition for livestock can be alleviated by searching for the potentials of these vast flora for fodder.

Among the promising trees in providing high quality protein feed sources for livestock are the legume species [5, 6]. Acacia species, especially Faidherbia albida, is a multipurpose tree species (MPTS) and is used as feed for livestock in most parts of arid and semi-arid regions of sub-Saharan West Africa. The tree is known as wonder tree that displayed excellent survival growth, and produces leaves and pods during dry season (January to February) when most trees shed their leaves. This quality makes $F$. albida worthy of investigation as a feed for livestock. In view of this, the present study was designated to evaluate the proximate and mineral composition of the seeds and pulp of F. albida with the hope that the information could be valuable in animal feed formulation.

\section{MATERIALS AND METHODS}

\section{Sample collection and preparation}

The mature and dried pods of Faidherbia albida were obtained in January and February from trees growing within Sokoto metropolis and the premises of the Usmanu Danfodiyo University, Sokoto, Nigeria.

The seeds and pulp were separated manually. Infected and stunted pods/seeds were discarded. The seeds and pulp were separately milled with mortar and pestle into fine powder, sieved to pass through 20 mesh sieve and stored in labelled polythene bags until required for analysis. The dried powdered samples were used for proximate and mineral analysis. 


\section{Proximate Analysis}

The methods for various analyses were the standard procedures of the AOAC [7]. Dry matter (DM) content was determined by drying two grams of each representative sample in an oven (Gallenkamp, UK) at $105{ }^{\circ} \mathrm{C}$ for 24 hours. Ash content was determined by the incineration of two grams of each sample in a muffle furnace (Lenton Furnaces, England) at $600{ }^{\circ} \mathrm{C}$ for 2 hours. Micro-Kjeldahl method was used to determine the nitrogen content of the samples; and the samples. Crude protein contents were estimated by multiplying their respective percentage nitrogen values by a factor 6.5 .

Crude lipid was extracted with n-hexane using a soxhlet apparatus, in each case, two grams sample was extracted for 8 hours. Crude fibre was estimated by acid-base digestion with $1.25 \% \mathrm{H}_{2} \mathrm{SO}_{4}(\mathrm{w} / \mathrm{v})$ and $1.25 \% \mathrm{NaOH}(\mathrm{w} / \mathrm{v})$ solutions. Available carbohydrates were calculated by difference by subtracting total sum of crude protein, crude lipid, crude fibre and ash from $100 \%$ DM. The samples' energy values were estimated in $\mathrm{kJ} / 100 \mathrm{~g} \mathrm{DM}$, by multiplying the percentages of crude protein, crude lipid and carbohydrate by the factors $17.7,37.7$ and 17.7 respectively, and summing up the values [8]. All determinations were carried out in triplicate and reported as mean $(\% \mathrm{DM}) \pm$ standard deviation.

\section{Mineral Analysis}

Mineral analysis was done after triple acid digestion by placing one gram-portion of each sample into Kjeldahl flask and digested with $24 \mathrm{ml}$ mixture of $\mathrm{HNO}_{3}, \mathrm{H}_{2} \mathrm{SO}_{4}$ and $\mathrm{HClO}_{4}(9: 2: 1 \mathrm{v} / \mathrm{v})$ until a clear solution was obtained. After cooling, the digest was filtered with Whatman No. 42 filter paper into a $50 \mathrm{~cm}^{3}$ volumetric flask to which 4 $\mathrm{ml}$ of $5 \%$ lanthanum chloride $\left(\mathrm{LaCl}_{3} .7 \mathrm{H}_{2} \mathrm{O}\right)$ solution was added to overcome phosphate interference. The flask was made up to the $50 \mathrm{~cm}^{3}$ mark with distilled water [9].

Copper, iron, calcium, magnesium and zinc were analysed with atomic absorption spectrophotometer (Alpha 4 model), Phosphorus content was determined colorimetrically using phospho-vanadomolybdate method with spectrophotometer 6100 model (Jenway, UK), while flame photometer (Corning 400, UK) was used for sodium and potassium analysis. All determinations were carried out in triplicate and reported as mean mineral content $(\mathrm{mg} / 100 \mathrm{~g} \mathrm{DM}) \pm$ standard deviation.

\section{Statistical Analysis}

The data generated were subjected to t-test Microsoft Excel statistical package, to compare the means composition of seed and pulp. Significance was accepted at $P \leq$ 0.05 .

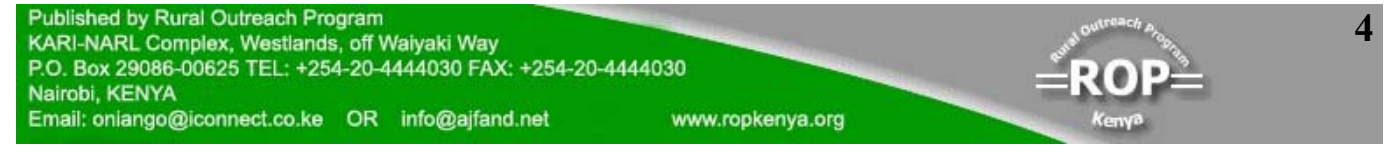




\section{RESULTS}

Table 1 shows the results of the proximate composition of the seed and pulp of Faidherbia albida. The samples' dry matter contents were found to be high $(90.0 \pm$ $0.4 \%$ for the seed and $93.3 \pm 0.2 \%$ for the pulp). The pulp DM was significantly ( $<<$ $0.05)$ higher than that of seed. Similarly, ash content is significantly $(\mathrm{p}<0.05)$ higher in pulp $(6.7 \pm 0.1 \%)$ compared to that of seed $(3.3 \pm 0.1 \%)$.

On the other hand, it was observed that the crude protein content in seed was higher $(20.63 \pm 1.2 \%)$ than that of pulp $(19.5 \pm 0.4 \%)$ even though not significant $(\mathrm{p}>$ $0.05)$. The seed sample also has a significantly $(\mathrm{p}<0.05)$ higher concentration of crude lipid $(13.3 \pm 0.1 \%)$ than the pulp sample $(3.3 \pm 0.1 \%)$. Furthermore, available carbohydrate is significantly $(\mathrm{p}<0.05)$ higher in pulp $(50.5 \pm 0.7 \%)$ when compared to seed $(40.1 \pm 0.1 \%)$. Crude fibre content was also significantly $(\mathrm{p}<0.05)$ higher in pulp $(13.3 \pm 0.2 \%)$ than in seed $(6.7 \pm 0.1 \%)$. The samples' energy values were observed to be significantly $(\mathrm{p}<0.05)$ higher in seed $(1,682 \mathrm{~kJ} / 100 \mathrm{~g})$ compared to pulp $(1,363 \mathrm{~kJ} / 100 \mathrm{~g})$. Table 2 shows the results of mineral composition in the seeds and pulp of $F$. albida. The results show that $\mathrm{Ca}, \mathrm{Mg}, \mathrm{K}, \mathrm{Na}, \mathrm{Cu}$ and $\mathrm{Zn}$ were significantly higher $(\mathrm{p}<0.05)$ in seeds compared to the pulp, while $\mathrm{P}$ and $\mathrm{Fe}$, were significantly higher $(\mathrm{p}<0.05)$ in the pulp.

\section{DISCUSSION}

The results for the proximate analysis showed that both the seeds and pulp of $F$. albida had high DM content. This is an indication that $F$. albida samples analysed constitute important, useful and dependable sources of DM for feeding livestock. The high DM content of the seed and pulp of $F$. albida which is an indication of low moisture content, show a better storage potential of the pods, since high moisture content is associated with increase of microbial activities during storage which reduces the nutritional value of feed material $[10,11]$. The values of the DM obtained in the present study are comparable with those reported for two species of Acacia tumida, and A. colei [12].

The ash content of the seeds and pulp of F. albida are $3.3 \%$ and $6.7 \%$, respectively. Akintayo [13] reported that ash content in feed ingredient to be used in compounding feed should be $<2.5 \%$. Nevertheless, the ash content could be brought within the range when mixed with other low ash containing feed ingredients. The ash content of the pulp obtained from the present study is high when compared with the value of 3.7 $\%$ reported in pods of Acacia albida grown in Tanzania [14], but compares favourably with the value of $6.3 \%$ found in pods of the same tree in the Republic of Niger [14]. Furthermore, the ash content reported herein compares favourably with the levels of ash in some feeding stuffs such as groundnut meal (6.0\%), cotton seed meal (5.82\%) and soya bean $(4.86 \%)[15,16]$.

The protein content of both the seed and pulp (Table 1) are relatively high. This could be attributed to the association of the plant with nitrogen-fixing bacteria [17]. The protein content reported here is comparable to the value reported in seeds of $A$. cole $i$

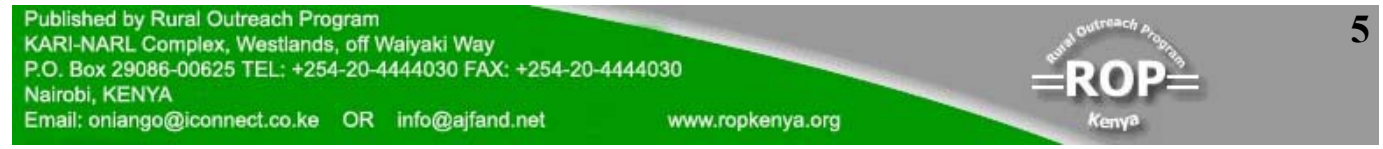


(23.4\%), but lower than that of A. tumida seed (34.1\%) [12]. The crude protein for the pulp $(19.5 \%)$ is higher than that of $A$. albida reported in Niger republic $(14.3 \%)$ and Tanzania (8.8\%) [14]. The differences could be due to genetic and eco-climatic variations. The result indicates that the protein content of the samples is adequate for meeting the maintenance requirement of small ruminants $(8.90 \%)$ as well as average requirements $(9.70 \%)$ for nursing cows in Nigeria [3]. The values are also above 10 $\%$ set by US National Research Council as maintenance requirement for sheep and goats [4]. Generally, the protein content of $F$. albida seeds and pulp is sufficiently high to affirm consideration of their use as plant protein sources in animal rations as high protein content in food if fully utilized by the body, will favour live weight gain and good animal performance.

The crude lipid content of the seeds was high, which indicates that the seeds might possibly be used as a source of oil in food, pharmaceuticals, cosmetics and alkyd resin preparations or used as biofuel $[18,19,20]$. However, further analysis is required to illustrate their tendencies in such applications. Also considering the protein content of the seed sample, if the oil is extracted, the cake produced as by-product could form a better feed ingredient with much higher protein content. The seed crude lipid content obtained in this study $(13.3 \%)$ is comparable to the 10.9 to $12.1 \%$ reported in the seed of $A$. colei [12]. The pulp crude lipid content is high, when compared to the values of $1.4 \%$ and $1.5 \%$ found in A. albida pods obtained in Tanzania and Republic of Niger, respectively [14]. This low lipid content makes the pulp suitable in feed formulation.

Carbohydrate content in both seeds (46.1\%) and pulp (50.5\%) was relatively high. The high fat and carbohydrate contents of the samples make the seeds and pulp flours of $F$. albida a good source of energy to livestock. The carbohydrate content of the pulp is comparable with the values of $53.2 \%$ and $61.7 \%$ reported in the pulp of the same tree grown in Republic Niger and Tanzania, respectively [14].

The crude fibre content of $F$. albida seeds $(6.7 \%)$ was low compared to that of Acacia colei (39.9\%) and Acacia tumida (20.3\%) [12] and some legume grains such as blue lupin (16.1\%) and yellow lupin (20.2\%), which are used as components of livestock feeds [21]. The pulp also has a low crude fibre value $(13.3 \%)$ that compared with $24.7 \%$ and $24.4 \%$ reported in the pulp of the same tree species grown in the Republic of Niger and Tanzania, respectively [14]. According to Shiawoya and Adeyemi [3], low fibre content of feeds could stimulate increased feed intake as well as enhance the quality and digestibility of the feed. In this study, the fibre contents of the two samples prove that they are unsuitable for animal feed compounding [13].

F. albida seeds have higher energy values than the pulp as shown in Table 1 . The relatively high energy value of the seed could be due to higher concentration of crude lipid in the seed compared to the pulp. This further confirms that fruits of $F$. albida pods are important sources of energy to livestock.

The results for mineral analysis reveal that calcium and magnesium content in the samples were significantly within the levels that are optimal for ruminants (Table 3 ).

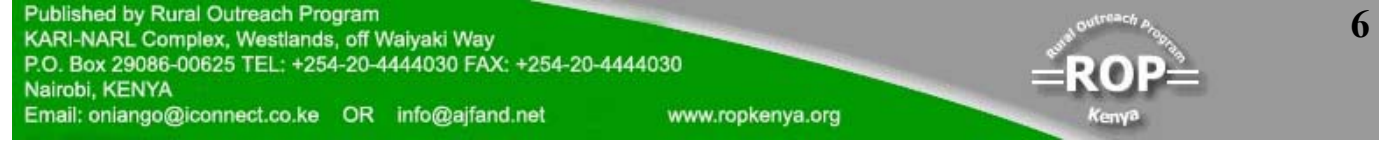




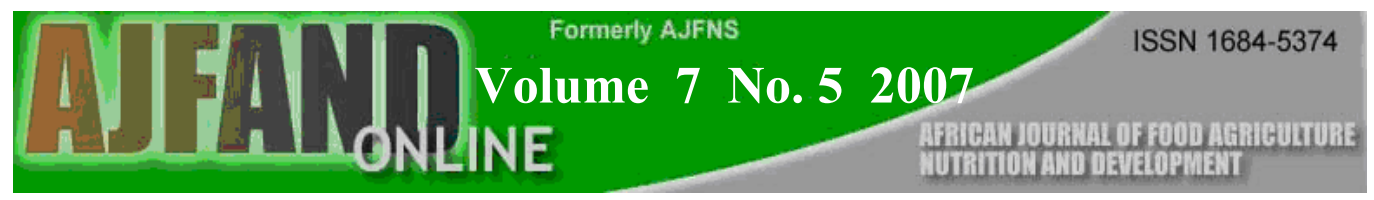

The phosphorus content in these samples is low $(26.6 \pm 0.9$ and $29.6 \pm 0.7$ $\mathrm{mg} / 100 \mathrm{gDW}$ ) compared to the recommended value, which is $120-480 \mathrm{mg}$ (Table 3 ). This low phosphorus value is of significant importance as calcium is closely related to phosphorus metabolism in the formation of bones with the tolerable limits of Ca:P ratio being in the range of $1: 1$ to $7: 1$ [22]. The Ca:P ratio in the present study ranged from 5:1 in the seeds to $2: 1$ in the pulp, which are within the tolerable limits. Thus, aphosphorosis and infertility in cattle due to intake of excess Ca is unlikely [22, 23]. The Ca:P ratio in this study shows that if $F$. albida seeds are mixed with cereal byproducts which are low in calcium and high in phosphorus [22] it could form a nutritious diet for livestock.

The concentrations of microelements (iron, copper, and zinc) in these samples are high considering the recommended values for ruminants (Table 3), thus indicating that $F$. albida seeds and pulp are good sources of these essential microelements. Generally, in most cases, ruminant animals consuming up to one kilogram per day of these seeds can fulfill up their macro elements requirement while between 12 to $81 \mathrm{~g}$ and 28 to $133 \mathrm{~g}$ of seeds and pulp, respectively, could provide the recommended dietary allowances for $\mathrm{Fe}, \mathrm{Cu}$ and $\mathrm{Zn}$ (Table 3), in all cases assuming total utilization of elements and ignoring the effect of toxicants and antinutritional factors.

\section{CONCLUSION}

The results of the present study indicated that the seeds and pulp of $F$. albida are good sources of plant protein and minerals, which might be an indication that they could be used as feed supplements for livestock. The seeds of $F$. albida could be a very useful source of oil for domestic and industrial uses. Furthermore, the cake obtained after oil extraction could be a good protein source for livestock. However, chemical analysis alone should not be the sole criterion for judging the nutritional importance of a particular feed ingredient. Thus, it becomes imperative to consider other aspects such as animal responses to nutritional potentials of the pods as well as its antinutritional and toxicological effects.

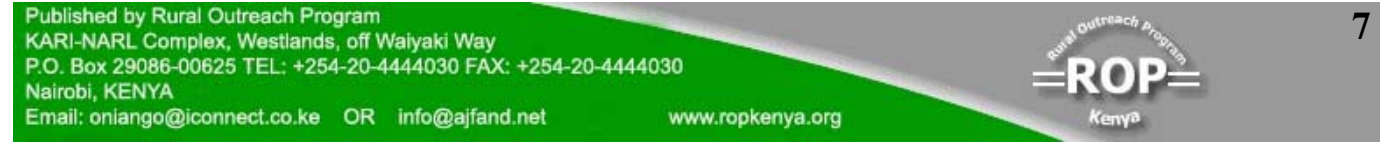




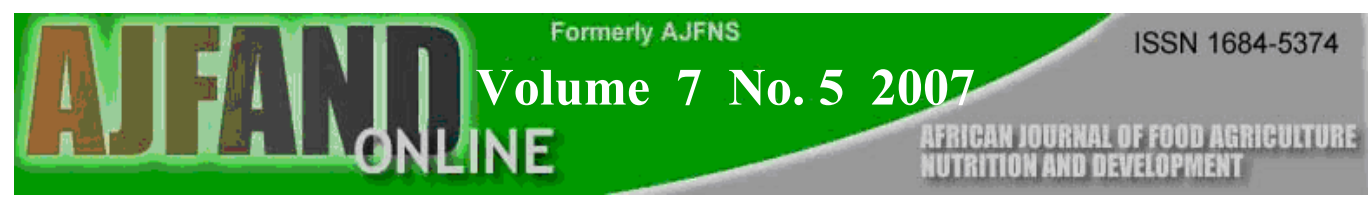

Table 1: Proximate composition of the seed and pulp of Faidherbia albida

\begin{tabular}{lcc}
\hline Parameters & Seed $(\% \mathrm{DM})$ & Pulp $(\% \mathrm{DM})$ \\
\hline Dry matter $(\mathrm{DM})$ & $90.0 \pm 0.4^{\mathrm{b}}$ & $93.3 \pm 0.2^{\mathrm{a}}$ \\
Ash & $3.3 \pm 0.1^{\mathrm{b}}$ & $6.7 \pm 0.1^{\mathrm{a}}$ \\
Crude protein & $20.6 \pm 1.2^{\mathrm{a}}$ & $19.5 \pm 0.4^{\mathrm{a}}$ \\
Crude lipid & $13.3 \pm 0.1^{\mathrm{a}}$ & $3.3 \pm 0.1^{\mathrm{b}}$ \\
Crude fibre & $6.7 \pm 0.1^{\mathrm{b}}$ & $13.3 \pm 0.2^{\mathrm{a}}$ \\
Carbohydrate & $46.1 \pm 0.1^{\mathrm{b}}$ & $50.5 \pm 0.7^{\mathrm{a}}$ \\
Energy value $(\mathrm{kJ} / 100 \mathrm{~g})$ & $1682^{\mathrm{a}}$ & $1363^{\mathrm{b}}$ \\
\hline
\end{tabular}

The data are mean value \pm standard deviation (SD) of three replicates. Values within a row marked with different superscript are significantly different $(\mathrm{p}<0.05)$.

Table 2: Mineral Composition of Seed and Pulp of Faidherbia albida

\begin{tabular}{lcc}
\hline Element & Seed $(\mathrm{mg} / 100 \mathrm{~g} \mathrm{DM})$ & Pulp $(\mathrm{mg} / 100 \mathrm{~g} \mathrm{DM})$ \\
\hline Calcium & $136.6 \pm 5.0^{\mathrm{a}}$ & $55.0 \pm 5.0^{\mathrm{b}}$ \\
Magnesium & $135.0 \pm 2.0^{\mathrm{a}}$ & $84.7 \pm 3.0^{\mathrm{b}}$ \\
Phosphorus & $26.6 \pm 0.9^{\mathrm{b}}$ & $29.6 \pm 0.7^{\mathrm{a}}$ \\
Potassium & $144.5 \pm 0.2^{\mathrm{a}}$ & $88.8 \pm 0.1^{\mathrm{b}}$ \\
Sodium & $12.5 \pm 0.1^{\mathrm{a}}$ & $6.8 \pm 0.1^{\mathrm{b}}$ \\
Iron & $6.2 \pm 0.2^{\mathrm{b}}$ & $8.8 \pm 0.3^{\mathrm{a}}$ \\
Copper & $5.8 \pm 0.1^{\mathrm{a}}$ & $2.5 \pm 0.1^{\mathrm{b}}$ \\
Zinc & $8.0 \pm 0.1^{\mathrm{a}}$ & $3.0 \pm 0.1^{\mathrm{b}}$ \\
\hline
\end{tabular}

The data are mean value \pm standard deviation (SD) of three replicates. Values within a row marked with different superscript are significantly different $(p<0.05)$. 


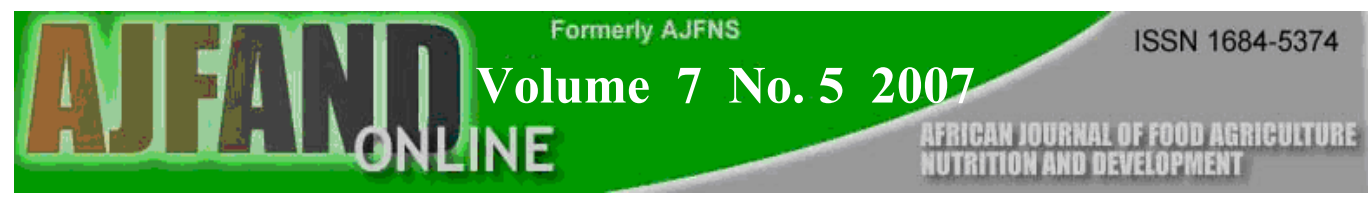

Table 3: Amount of seeds and pulp of Faidherbia albida to be consumed to give the minerals recommended dietary levels for Ruminants

\begin{tabular}{lccc}
\hline Mineral & $\begin{array}{c}* \text { Recommended dietary } \\
\text { levels for Ruminants }(\mathrm{mg})\end{array}$ & $\begin{array}{c}\text { Seeds } \\
(\mathrm{mg})\end{array}$ & $\begin{array}{c}\text { Pulp } \\
(\mathrm{mg})\end{array}$ \\
\hline $\mathrm{K}$ & $500-1,000$ & $346-692$ & $563-1,126$ \\
$\mathrm{Na}$ & $60-180$ & $480-1,440$ & $878-2,635$ \\
$\mathrm{Ca}$ & $190-820$ & $139-600$ & $345-1,491$ \\
$\mathrm{Mg}$ & $100-250$ & $74-185$ & $118-295$ \\
$\mathrm{P}$ & $120-480$ & $451-1,805$ & $402-1,608$ \\
$\mathrm{Fe}$ & $3.0-5.0$ & $48-81$ & $34-57$ \\
$\mathrm{Cu}$ & $0.7-1.1$ & $12-19$ & $28-44$ \\
$\mathrm{Zn}$ & $2.0-4.0$ & $25-50$ & $67-133$ \\
\hline
\end{tabular}

*Source: Khanal and Subba, 2001. 


\section{REFERENCES}

1. Castillo-Caamal JB, Jimenez-Osornio JJ, Lopez-Perez A, AguilarCordero W and AM Castillo-Caamal Feeding Mucuna beans to small ruminants of Mayan farmers in the Yucatan Peninsula, Mexico. Tropical and Subtropical Agroecosystems 2003; 1: 113 - 117.

2. Matenga VR, Ngongoni NT, Titterton M and BV Maasdorp Mucuna seed as a feed ingredient for small ruminants and effect of ensiling on its nutritive value. Tropical and Subtropical Agroecosystems 2003; 1: 97-105.

3. Shiawoya EL and AA Adeyemi Nutrient composition of mixed forages growing on Bosso Campus of the Federal University of Technology (FUT) Minna, Niger State, Nigeria. Science Forum: Journal of Pure and Applied Sciences 2003; 6(2): 213 - 218 .

4. Oladotun OA, Aina ABJ and EB Oguntona Evaluation of formulated agroIndustrial wastes as dry season feed for sheep. Nigerian Journal of Animal Production 2003; 30: 71-80.

5. Abdulrazak SA, Fujihara T, Ondiek JK and ER Orskov Nutritive evaluation of some Acacia tree leaves from Kenya. Animal Feed Science and Technology 2000; 85: 89-98.

6. Rumirez-Orduna R, Ramirez RG, Gonzalez-Rodriguez $H$ and GFW Haenlein Mineral content of browse species from Baja California Sur, Mexico. Small Ruminant Research 2005; 57(1): 1 -10.

7. AOAC. Official Methods of Analysis, $14^{\text {th }}$ edition, Association of Official Analytical Chemists, Washington D.C, 1990.

8. Vadivel $\mathbf{V}$ and $\mathbf{K}$ Janardhanan Nutritional and antinutritional attributes of sword bean [Canavalia gladiata (Jacq.) DC.]: An under-utilized tribal pulse from south India. International Journal of Food Science and Technology 2004; 39: $917-926$.

9. Hassan LG and KJ Umar Proximate and mineral compositions of seeds and pulp of Parkia biglobosa L. Nigerian Journal of Basic and Applied Sciences 2004; 13: 15-27.

10. Abdullahi SA Evaluation of the nutrient composition of some fresh-water fish families in Northern Nigeria. Journal of Agriculture and Environment 2000; 1(2): $141-150$.

11. Tona GO, Agyemang K, Adeneye JA and JA Akinlade Chemical composition and rumen degradation of diet combinations of cottonseed cakes, dried brewers grains and Lablab parpareus hay incubated in the rumen of 
fistulated N'Dama steers in South-western Nigeria. Nigerian Journal of Animal Production 2003; 30: 47-56.

12. Adewusi SRA, Falade, OS and C Harwood Chemical composition of Acacia tumida seeds-potential food sources in the semi-arid tropics. Food Chemistry 2003; 80: $187-195$.

13. Akintayo ET Characteristics and composition of Parkia biglobosa and Jatropha curcas oils and cakes. Bioresource Technology 2004; 92: 307 -310.

14. Gohl B tropical feeds. Feed information summaries and nutritive value. FAO animal production and Health Series 12. FAO, Rome, 1981.

15. Nzekwe NM and JM Olomu The evaluation of cottonseed meal as replacement for groundnut meal in broiler rations. Journal of Animal Production and Research 1982; 2(2): 123-138.

16. Fasoyiro, SB, Ajibade, SR, Omole, AJ, Adeniyan, ON and EO Farinde Proximate, minerals and antinutritional factors of some underutilised grain legumes in south-western Nigeria. Nutrition and Food Science 2006; 36(1): 18 -23 .

17. Oboh G and MM Ekperigin Nutritional evaluation of some Nigerian wild seeds. Nahrung/Food 2004; 48(2): 85-87.

18. Lalas $\mathbf{S}$ and $\mathbf{J}$ Tsaknis Characterization of Moringa oleifera seed oil variety "Periyakulam 1". Journal of Food Composition and Analysis 2002; 15(1): 65 -77 .

19. Eromosele IC, Eromosele CO, Innazo $\mathbf{P}$ and $\mathbf{P}$ Njerim Studies on some seeds and seed oils. Bioresource Technology 1998; 64: 245-247.

20. Okieimen FE and CO Eromosele Fatty acid composition of the seed oil of Khaya senegalensis. Bioresource Technology 1999; 69: 279-280.

21. Abreu JMF and AMB Soares Chemical composition and organic matter digestibility and gas production of nine legume grains. Animal Feed Science and Technology 1998; 70: 49-57.

22. Kallah MS, Bale JO and US Abdullahi Nutrient composition of native forbs of semi-arid and dry sub-humid savannas of Nigeria. Animal Feed Science and Technology 2000; 84: 137 - 145 .

23. Khanal RC and DB Subba Nutritional evaluation of leaves from major fodder trees cultivated in the hills of Nepal. Animal Feed Science and Technology 2001; 92: 17-32. 